\title{
Effect Incorporated of Oat and Corn Cob Powder on Physicochemical and Sensory Properties of Putu Piring
}

\author{
Fisal Ahmad ${ }^{\mathrm{a}^{*}}$, Nur Ezzliana Ismaila ${ }^{\mathrm{a}}$, Tuan Zainazor Tuan Chilek $^{\mathrm{a}}$, Amir Izzwan Zamri ${ }^{\mathrm{a}}$, Mohamad \\ Khairi Mohd Zainol ${ }^{\mathrm{a}}$, Rahijan Abdul Wahab ${ }^{\mathrm{a}}$, Mansoor Abdul Hamid ${ }^{\mathrm{b}}$ \\ ${ }^{a}$ Faculty of Fisheries and Food Science, Universiti Malaysia Terengganu, 21030 Kuala Nerus, Terengganu, Malaysia \\ ${ }^{b}$ Faculty of Food Science and Nutrition, Universiti Malaysia Sabah, Jalan UMS, 88400 Kota Kinabalu, Sabah, Malaysia \\ fisal@umt.edu.my* \\ * corresponding author
}

ARTICLE INFO ABSTRACT

\section{Article history:}

Received: 05-01-2021

Revised: 03-03-2021

Accepted: 29-04-2021

Keywords:

Product development

Traditional food

Fibre

Healthy food

By product

\begin{abstract}
The growing consumer demand for healthy food products has turned the interest of industry and researcher in the development of foods enriched with fibre source. Oat and corn cob powder is one of the fibre sources that rich in insoluble fibers, such as cellulose, hemicellulose and lignin which beneficial the consumer in many ways for a healthy diet. The objective of this study was to investigate the effect of oat and corn cob powder incorporation on the sensory acceptability and physicochemical properties of putu piring at different levels of percentage ratio of oat and corn cob (control 0\% OP: 0\% CCP A, 0\% OP: $100 \%$ CCP B, 30\% OP:70\% CCP C, 50\% OP:50\% CCP D, 70\% OP:30\% CCP E and 100\% OP: 0\% CCP F). Physical analysis showed that the colour of putu piring for L* value ranges from 74.17 to 19.76 , a* value ranges from 0.23 to 1.90 and $b^{*}$ value ranges from 13.97 to 20.65 . Sensory evaluation results showed that putu piring control (formulation A) scored the highest and no significant different $(\mathrm{p}<0.05)$ compare followed by 30\% OP: $70 \%$ CCP (formulation C) and 50\% OP: $50 \%$ CCP (formulation D) in all attributes being evaluated. Proximate analysis showed that putu piring incorporated with oat and corn cob powder has significantly different $(p<0.05)$ in terms of crude fibre content. It is interesting to note that the incorporation of oat and corn cob powder yielded putu piring can im-proves the nutritive value of the product to become high fibre products.
\end{abstract}

Copyright (C) Author

\section{Introduction}

Putu piring is one of the popular local Malay snacks. It is called putu piring because it is made of ground rice flour, it is shaped by conical molds into circular mounds. However, the putu piring was not meet the satisfaction in nutritional value content, which is a main ingredient of putu piring rice flour is low in fiber and no research occurred on development of putu piring by using oat powder (OP) and corn cob powder (CCP) as functional ingredients. Nowadays, the food industry is investing a great deal of effort in increasing the usage of oat as ingredient for formulating novel food products. Therefore, our local traditional food products also need to be improved and follow the market trend (Muhammad et al., 2017).

According to (Liukkonen et al., 1992), oat is rich in protein and dietary fiber and its content of fatty acids is favorable. On the other hand, the corncob (CC) is an agricultural waste that is always being disposed as a trash. According to (Faostat, 2016), the total amount of corn production in Malaysia alone increased to 86,643 tons in 2014 from 47,602 tons in 2010. On the downside, one of the main wastes from the corn industry is $\mathrm{CC}$. Huge amounts of $\mathrm{CC}$ were produced considering the proportion between corn kernels and CC may reach (Cao et al., 2006). This is because only $60 \%$ of corns are edible during its maturity while the remaining $40 \%$ had turned into waste (Yusnita \& Wong, 2011).

According to (Abubakar et al., 2016), corncob had high amount of crude fiber $(33.33 \pm 0.21 \%)$. Thus corncob, which is high in fiber will increase in their nutritional content as well as corncob may 
be regarded as valuable additives to rice flour. However, there were no reported studies carried out incorporated with oat and corncob powder in the development of putu piring. High fiber content in diets have been reported to result in increased removal of potential mutagens, steroids and xenobiotics by binding or absorbing to dietary fiber components and thereby aids digestion. Therefore, this study might provide information related the suitability of fiber from oat and corn cob powder in development of putu piring high fiber (Jaworska et al., 2020).

\section{Method}

\section{A. Raw Materials}

Basic ingredients used for this study such as rice flour, palm sugar, salt, shredded coconut, oatmeal, and fresh corn were collected from the local market in Kuala Terengganu. They were taken to the laboratory for immediate processing. Oat was turn into powder by using a blender along with a grinder and for corn cob powder were prepared by using a modification method by (Olaoye et al., 2007).

\section{B. Formulation of putu piring incorporated with oat and corn cob powder}

There were six formulations of putu piring incorporated with oat and corn cob powder including control. Table 1 was shown the formulation of putu piring incorporated with difference ratio percentage of oat powder and corn cob powder. These formulations were modified by incorporating difference ratio of oat powder and corn cob powder by varying the amount of oat powder and corn cob powder used in the formulation which were: $0 \%$ OP: 0\% CCP A; 0\% OP: $100 \%$ CCP B; $30 \%$ OP: $70 \%$ CCP C; $50 \%$ OP: $50 \%$ CCP D; $70 \%$ OP: $30 \%$ CCP E; and $100 \%$ OP: $0 \%$ CCP F. The percentage ratio of oat and corn cob powder was calculated using weight-by-weight ratio. Other basic ingredients that used in the preparation include rice flour, water, grated palm sugar, freshly shredded coconut, and salt,

Table 1. Formulation of putu piring incorporated with oat powder and corncob powder.

\begin{tabular}{ccccccc}
\hline Ingredients & \multicolumn{6}{c}{ Formulation Oat Powder (OP): Corncob Powder (CCP) } \\
Sample & A & B & C & D & E & F \\
\hline Percentage ratio & $(0: 0)$ & $(0: 100)$ & $(30: 70)$ & $(50: 50)$ & $(70: 30)$ & $(100: 0)$ \\
Rice Flour $(\mathrm{g})$ & 120 & 90 & 90 & 90 & 90 & 90 \\
Oat powder $(\mathrm{g})$ & - & - & 9 & 15 & 21 & 30 \\
Corncob powder $(\mathrm{g})$ & - & 30 & 21 & 15 & 9 & - \\
*Shredded coconut $(\mathrm{g})$ & 18 & 18 & 18 & 18 & 18 & 18 \\
*Grated Palm Sugar (g) & 25 & 25 & 25 & 25 & 25 & 25 \\
* Salt (g) & 1.5 & 1.5 & 1.5 & 1.5 & 1.5 & 1.5 \\
*Water (ml) & 75 & 75 & 75 & 75 & 75 & 75 \\
\hline
\end{tabular}

a. Note: Ingredients labelled with $(*)$ shows the constant ingredients

\section{Preparation of putu piring incorporated with oat and corn cob powder}

Preparation of putu piring incorporated with oat and corn cob powder was modified from (W. Tee, 2020). Firstly, all the ingredients were weighted accurately. After that, in a mixing bowl, rice flour, oat powder, corn cob powder, sea salt, and water were combined and mixed. The flour and other ingredients were rub with a finger until they resemble fine breadcrumbs. After sieved, set the steamer on, once the water boiled, the heat was reduced to medium. Then, the flour mixed was filled about $10 \mathrm{~g}$ into a small saucer or mold, top with $5 \mathrm{~g}$ of grated palm sugar, and was covered with another $10 \mathrm{~g}$ of flour mixed. The flour mixed was lightly press into the saucer and cover with a piece of muslin cloth over it. The filled saucer was steam for about 7 minutes, remove from the steamer, top the putu piring with some grated coconut and carefully remove the muslin cloth.

\section{Colour profile analysis}

The color profile of putu piring was measured with a CR 300 Konica Minolta Chromameter (Konica Minolta Sensing Inc, Osaka Japan) with a $50 \mathrm{~mm}$ diameter measuring tube, using a white tile background. CIE L* $\mathrm{a}^{*} \mathrm{~b}^{*}$ values donate lightness, redness-greenness, and yellowness-blueness, respectively. Firstly, calibration was done on the machine. A sample of putu piring sheet was placed on granular material attachment and compacted. Then, the granular materials attachment was inserted into the Minolta Chromameter. Putu piring color results were reported in terms of 3- 
dimensional color values based on the rating scale which was CIE $\mathrm{L}^{*} \mathrm{a}^{*} \mathrm{~b}^{*}$ values. The result was taken in two times.

\section{E. Proximate analysis}

Only for the putu piring incorporated with oat and corn cob powder that has been accepted by panelists which are Formulation A (Control), Formulation C (30\% OP: 70\% CCP), and Formulation D (50\% OP: 50\% CCP) were determine their moisture content, ash content, crude protein content, crude fat content, crude fiber content, and carbohydrate content (by difference) (Ahmed et al., 2009; Horwitz, 2000). The results were shown as $\%$ wet basis.

\section{F. Sensory evaluation}

A sensory evaluation was carried out to determine the acceptance of the putu piring incorporated with oat and corn cob powder. There were 30 untrained panels who were the students of Universiti Malaysia Terengganu were chosen randomly and were required to do an acceptance test to evaluate all the formulation A to F of putu piring. Acceptance test (Lee et al., 2019) was carried out using 7points hedonic scale, ranging from 1 (dislike extremely) to 7 (like extremely) for each attribute. The evaluated attributes were appearance, color, aroma, texture, taste, and overall acceptability. The sample was served in mold plastic and coded with 3 digits random numbers. For a sample to be consider as acceptable, 3 was the minimum mean score for overall acceptability.

\section{G. Statistical analysis}

The data was reported as a mean \pm standard deviation. The data for chemical and physical analysis was subjected to one way analysis of variance (ANOVA) by using Minitab 18. Tukey's test was conducted to examine significance difference of mean values $(\mathrm{p}<0.05)$ for all responses.

\section{Results and Discussion}

\section{A. Colour profile of Putu pring incorporated with oat and corn cob powder}

The effect of different amount of oats and corn cobs powder on color development of putu piring was examined in terms of CIE L* $\mathrm{a}^{*} \mathrm{~b}^{*}$ values. Table 2 showed the values of $\mathrm{L}^{*}, \mathrm{a}^{*}, \mathrm{~b}^{*}$ of the putu piring. The $\mathrm{L}^{*}$ value for the formulation $\mathrm{F}$ is higher than other formulations. This is maybe because of the color the oat and rice flour itself give a high value of lightness. Meanwhile, there were no significant differences between the formulation A (Control), formulation C (70\% OP: 30\% CCP) and formulation D (50\% OP: 50\% CCP). However, there was significant difference $(\mathrm{p}<0.05)$ on the lightness $\mathrm{L}^{*}$ value between the formulation B (0\% OP: $100 \%$ CCP), formulation E (70\% OP: $30 \%$ CCP) and formulation F (100\% OP: 0\% CCP). The increase differences of lightness sample of the formulations may be due to oat powder and corncob powder addition.

The $\mathrm{a}^{*}$ value for all samples showed the values ranging from 0.23 to 1.90 . The results showed there were no significant difference between the formulation A (0\% OP: $0 \% \mathrm{CCP})$, formulation $\mathrm{C}$ (30\% OP: $70 \%$ CCP) and formulation D (50\% OP: 50\% CCP). However, there were significant differences between the formulation A (0\% OP: 0\% CCP), formulation B (100\% OP: 0\% CCP), formulation E (70\% OP: 30\% CCP) and formulation F (100\% OP: 0\% CCP). For the $b^{*}$ value, the results showed the same paten, there was no significant difference between formulation A ( $0 \%$ OP: $0 \% \mathrm{CCP})$, formulation C (30\% OP: $70 \% \mathrm{CCP}$ ) and formulation D (50\% OP: 50\% CCP). The different amount of the corn cob powder developed a yellowish color to the putu piring. According to (Lee et al., 2019) the value of $b^{*}$ (yellowness) also significantly increased at ( $\left.p<0.05\right)$ with increasing content of CCP in the high fibre bread. This may be due to the natural yellow pigmentation of CCP.

Table 2. Colour profile of putu piring incorporated with oat and corn cob powder.

\begin{tabular}{cccc}
\hline Formulations & $\begin{array}{c}\mathrm{L}^{*} \\
\text { Mean } \pm \text { Standard deviation }\end{array}$ & $\begin{array}{c}\mathrm{a}^{*} \\
\text { Mean } \pm \text { Standard deviation }\end{array}$ & $\begin{array}{c}\mathrm{b}^{*} \\
\text { Mean } \pm \text { Standard deviation }\end{array}$ \\
\hline A & $76.70 \pm 0.17_{\mathrm{c}}$ & $1.49 \pm 0.11_{\mathrm{b}}$ & $18.91 \pm 0.01_{\mathrm{b}}$ \\
$\mathrm{B}$ & $74.17 \pm 0.23_{\mathrm{d}}$ & $1.90 \pm 0.01_{\mathrm{a}}$ & $20.65 \pm 0.22_{\mathrm{a}}$ \\
$\mathrm{C}$ & $76.81 \pm 0.42_{\mathrm{c}}$ & $1.55 \pm 0.15_{\mathrm{b}}$ & $19.43 \pm 0.08_{\mathrm{b}}$ \\
$\mathrm{D}$ & $77.09 \pm 0.15_{\mathrm{c}}$ & $1.43 \pm 0.04_{\mathrm{b}}$ & $18.35 \pm 0.37_{\mathrm{b}}$ \\
$\mathrm{E}$ & $78.33 \pm 0.22_{\mathrm{b}}$ & $0.47 \pm 0.13_{\mathrm{c}}$ & $17.72 \pm 0.00_{\mathrm{c}}$ \\
F & $79.76 \pm 0.28_{\mathrm{a}}$ & $0.23 \pm 0.06_{\mathrm{d}}$ & $13.97 \pm 0.11_{\mathrm{d}}$ \\
\hline
\end{tabular}


b. Values mean \pm standard deviation of three replication. Mean value in the same column with the same superscript letter showed no significant different $(\mathrm{p}>0.05)$.

\section{B. Sensory Evaluation}

The sensory evaluation scores of putu piring incorporated with OP and CCP are summarized in Table 3. The results showed that all the attributes have scores above category 3 (neither like nor dislike), considered in the present work as the minimum acceptable value. The mean score for appearance attributes was in the range of 4.20 and 5.80. The putu piring incorporated with ratio $0 \%$ OP: $100 \%$ CCP (formulation B) was significantly the lowest (4.20) among all the samples. In terms of appearance, formulation A (0\% OP: $0 \% \mathrm{CCP})$ had the highest score (5.80) as compared to other samples and its score was not significantly difference from formulation C (30\% OP: 70\% CCP) and formulation D (50\% OP: $50 \%$ CCP).

Similar pattern to the color score of putu piring incorporated with oat and corn cob powder, putu piring formulation A (0\% OP: $0 \%$ CCP) had the highest score (5.40) in terms of color as compared to other samples and its score was not significantly difference ( $\mathrm{p}>0.05)$ from formulation $\mathrm{C}(30 \%$ OP: $70 \% \mathrm{CCP}$ ) and formulation D (50\% OP: 50\% CCP). These samples were significantly difference $(\mathrm{p}<0.05)$ with other samples. The color of the putu piring incorporated with oat powder and corn cob powder were affected by the color of OP and CCP color.

Table 3. Sensory evaluation results of putu piring incorporated with oat and corn cob powder.

\begin{tabular}{|c|c|c|c|c|c|c|}
\hline & Appearance & Colour & Aroma & Taste & Texture & Overall acceptability \\
\hline $\bar{A}$ & $5.80 \pm 0.66^{a}$ & $5.40 \pm 0.86^{a}$ & $5.40 \pm 0.79^{a}$ & $4.57 \pm 0.77^{a}$ & $4.20 \pm 0.55^{a}$ & $4.60 \pm 0.62^{a}$ \\
\hline B & $4.20 \pm 0.65^{c}$ & $4.27 \pm 0.80^{\circ}$ & $4.05 \pm 1.23^{b}$ & $3.67 \pm 1.27^{b}$ & $3.63 \pm 1.18^{b}$ & $3.53 \pm 1.20^{b}$ \\
\hline $\mathrm{C}$ & $5.23 \pm 0.73^{a b}$ & $5.07 \pm 0.91^{a b}$ & $4.83 \pm 0.80^{a b}$ & $4.10 \pm 0.76^{a b}$ & $3.87 \pm 0.68^{a b}$ & $4.23 \pm 0.68^{a b}$ \\
\hline $\mathrm{D}$ & $5.03 \pm 0.81^{a b}$ & $5.10 \pm 0.95^{a b}$ & $4.97 \pm 1.01^{a b}$ & $4.23 \pm 0.82^{a b}$ & $3.73 \pm 0.87^{a b}$ & $4.23 \pm 0.77^{a b}$ \\
\hline $\mathrm{E}$ & $4.50 \pm 1.08^{b}$ & $4.70 \pm 1.09^{b}$ & $4.13 \pm 1.11^{b}$ & $3.60 \pm 1.25^{b}$ & $3.40 \pm 1.13^{c}$ & $3.60 \pm 1.28^{b}$ \\
\hline $\mathrm{F}$ & $4.53 \pm 1.04^{b}$ & $4.40 \pm 0.83^{c}$ & $4.00 \pm 1.29^{b}$ & $3.60 \pm 1.59^{b}$ & $3.20 \pm 1.34^{c}$ & $3.50 \pm 1.61^{b}$ \\
\hline
\end{tabular}

c. Means scores for different attributes tested in sensory evolution of putu piring incorporated with oat and corn cob powder with 7-point hedonic scale. Mean value in the same column with the same superscript letter showed no significant different $(\mathrm{p}>0.05)$.

The range of means score for aroma attributes of putu piring incorporated with oat and corn cob powder were 4.00 to 5.40 . The aroma most prefer by the panelists was the putu piring prepared without any incorporation of the oat and corn cob powder formulation A (0\% OP: 0\% CCP) (5.40). The incorporation of the oat and corn cob powder might contribute changes in aroma of putu piring due to OP and CCP have their own aroma characteristic. The means score for the taste attributes of all samples were in the range of 3.60 to 4.57 . Formulation E, F and B was significantly lower ( $\mathrm{p}<$ $0.05)$ mean score $(3.60,3.60,3.67)$ compared to Formulation A, C, and D $(4.57,4.10,4.23)$. The changes in taste were most probably caused by CCP that had strong aroma and taste of corn so if it were added too much into the formulation, the taste and aroma of the putu piring would be altered.

The means score for the texture attributes of putu piring incorporated with oat and corn cob powder showed the score ranging from 3.20 to 4.20 . The highest mean score and most preferable texture was putu piring with formulation A ( $0 \%$ OP: $0 \%$ CCP) followed by formulation C (30\% OP: $70 \% \mathrm{CCP}$ ) and D (50\% OP: 50\% CCP) with no significant difference ( $\mathrm{p}>0.05)$ among them. While the lowest mean score and less preferable texture by the panelist is formulation $\mathrm{F}$ (100\% OP: 0\% CCP) (3.20). The overall acceptance of putu piring incorporated with oat and corn cob powder by panelist were between 3.50 and 4.60 means score. Like the score of texture, the formulation A (0\% OP: $0 \%$ CCP) had the highest mean score in terms of overall acceptance among all the other putu piring samples. This formulation showed no significant difference $(\mathrm{p}>0.05)$ between formulation C (30\% OP: $70 \%$ CCP) and D (50\% OP: 50\% CCP). To consider a putu piring sample to be acceptable, its score of overall acceptability must be higher than 3 . Thus, all putu piring samples in this sensory evaluation were considered as acceptable since all scores of overall acceptability were higher than 3 . Furthermore, the scores also suggested that it was possible to increase the fiber content of putu piring with OP and CCP while still maintaining high acceptability from the consumers at the same time. From the results, Formulation C and D appeared to have high potential to introduce in the current putu piring market as it was comparable with control (Formulation A) and had insignificant difference, at $\mathrm{p}=0.05$. 


\section{Proximate composition}

The result of the proximate analysis of putu piring formulation $\mathrm{A}, \mathrm{C}$ and $\mathrm{D}$ are tabulated in Table 4. All the proximate parameters showed no significant differences ( $>0.05)$ between formulation $A$ (control), formulation C (30\% OP: 70\% CCP) and D (50\% OP: 50\% CCP) from the obtained results, except for crude fibre content. The crude fiber content of putu piring formulation A, formulation $\mathrm{B}$ and formulation $\mathrm{D}$, were $0.93 \%, 3.15 \%$ and $3.14 \%$, respectively. The result for formulation A (control) was in line with previous study by (E. S. Tee et al., 1997) where the crude protein content of putu piring is $0.90 \%$ has been reported.

Table 4. Proximate composition of putu piring incorporated with oat and corn cob powder.

\begin{tabular}{ccccccc}
\hline $\begin{array}{c}\text { Formulation } \\
\text { Putu piring }\end{array}$ & $\begin{array}{c}\text { Moisture } \\
\text { content } \\
(\boldsymbol{\%})\end{array}$ & $\begin{array}{c}\text { Ash } \\
\mathbf{( \% )}\end{array}$ & $\begin{array}{c}\text { Crude Protein } \\
\mathbf{( \% )}\end{array}$ & $\begin{array}{c}\text { Crude } \\
\text { Fat } \\
(\boldsymbol{\%})\end{array}$ & $\begin{array}{c}\text { Crude } \\
\text { fiber } \\
(\boldsymbol{\%})\end{array}$ & $\begin{array}{c}\text { Carbohydrate } \\
(\boldsymbol{\%})\end{array}$ \\
\hline $\mathrm{A}$ & $43.08 \pm 1.51 \mathrm{a}$ & $1.24 \pm 0.11 \mathrm{a}$ & $3.84 \pm 0.23 \mathrm{a}$ & $1.22 \pm 0.30 \mathrm{a}$ & $0.93 \pm 0.09 \mathrm{~b}$ & $49.69 \pm 1.43 \mathrm{a}$ \\
\hline $\mathrm{C}$ & $43.53 \pm 1.29 \mathrm{a}$ & $1.28 \pm 0.19 \mathrm{a}$ & $3.52 \pm 0.30 \mathrm{a}$ & $1.12 \pm 0.42 \mathrm{a}$ & $3.15 \pm 0.29 \mathrm{a}$ & $47.10 \pm 1.82 \mathrm{a}$ \\
\hline D & $44.64 \pm 1.56 \mathrm{a}$ & $1.37 \pm 0.14 \mathrm{a}$ & $3.63 \pm 0.40 \mathrm{a}$ & $1.57 \pm 0.10 \mathrm{a}$ & $3.14 \pm 0.18 \mathrm{a}$ & $46.06 \pm 1.56 \mathrm{a}$ \\
\hline \multicolumn{6}{c}{ d. Values are the means of three independent determinations. Means with the same letter do not differ significantly (p>0.05). }
\end{tabular}

Sample putu piring formulation A content the lowest amount of crude fiber and significantly ( $<<$ $0.05)$ lower compared to formulation C (30\% OP: $70 \%$ CCP) and D (50\% OP: $50 \%$ CCP). The addition of $\mathrm{OP}$ and $\mathrm{CCP}$ in putu piring resulted on the increasing amount of crude fiber content in the studied samples. According to (Aniola et al., 2009), the crude fiber content for CCP is high, so that can give a high fiber content in food product incorporated with CCP. This finding also been sported by (Kuan et al., 2011) reported that the CCP was processed from corn cob which contained primarily of insoluble fiber. Thus, $\mathrm{CCP}$ had the advantage to be used in bakery products including bread to increase their fiber content due to the high fiber content in CCP (Lee et al., 2019).

\section{Conclusion}

Thus, in the light of scientific data of the present investigation, it may be concluded that that oat and corn cob powder can be used successfully in preparation of putu piring at the replacement formulation C (30\% OP: $70 \%$ CCP) and formulation D (50\% OP: $50 \%$ CCP) without any undesirable changes in physical and organoleptic attributes of putu piring. It is interesting to note that the incorporation of oat and corn cob powder yielded putu piring not only improved the overall acceptability of the product but also improves the nutritive value of the product to become high fiber products. From all the results obtained, OP and CCP was concluded to have high potential to be utilized in other food products to improve their nutritional properties particularly in terms of fiber content, and physicochemical and sensory properties. Thus, from this study we successfully improve our local traditional food to be competitive and fulfil the consumer needs.

\section{References}

Abubakar, U. S., Yusuf, K. M., Safiyanu, I., Abdullahi, S., Saidu, S. R., Abdu, G. T., \& Indee, A. M. (2016). Proximate and Mineral Composition of Corn Cob, Banana and Plantain Peels. International Journal of Food Science and Nutrition, 1(6), 25-27.

Ahmed, S. A., Kadam, J. A., Mane, V. P., Patil, S. S., \& Baig, M. M. V. (2009). Biological Efficiency and Nutritional Contents of Pleurotus Florida (Mont.) Singer Cultivated on Different Agro-Wastes. Nature and Science, 7(1), 44-48.

Aniola, J., Gawecki, J., Czarnocinska, J., \& Galinski, G. (2009). Corncobs as A Source of Dietary Fiber. Polish Journal of Food and Nutrition Sciences, 59(3).

Cao, Q., Xie, K. C., Lv, Y. K., \& Bao, W. R. (2006). Process Effects on Activated Carbon with Large Specific Surface Area from Corn Cob. Bioresource Technology, 97(1), 110-115.

Faostat, F. (2016). Agriculture Organization of The United Nations Statistics Division. In Economic and Social Development Department, Rome, Italy. Available online: http://faostat3. fao. org/home.

Horwitz, W. (2000). Official Methods of Analysis (17 th edit). Association of Official Analytical Chemists Washington, DC. 
Jaworska, D., Królak, M., \& Jeżewska-Zychowicz, M. (2020). Reformulation of Bread Rolls Using Oat Fibre: An Acceptable Way of Dietary Fibre Enrichment? Nutrition Bulletin, 45(2), 189-198.

Kuan, C. Y., Yuen, K. H., Bhat, R., \& Liong, M. T. (2011). Physicochemical Characterization of Alkali Treated Fractions from Corncob and Wheat Straw and The Production of Nanofibers. Food Research International, 44(9), 2822-2829.

Lee, C. M., Gan, Y. L., Chan, Y. L., Yap, K. L., Tang, T. K., Tan, C. P., \& Lai, O. M. (2019). Physicochemical and Sensory Analyses of High Fibre Bread Incorporated with Corncob Powder. International Food Research Journal, 26(5), 1609-1616.

Liukkonen, K. H., Montfoort, A., \& Laakso, S. V. (1992). Water-Induced Lipid Changes in Oat Processing. Journal of Agricultural and Food Chemistry, 40(1), 126-130.

Muhammad, N. A. A. N., Lee, C. P., Lim, K. M., \& Razak, S. F. A. (2017). Malaysian Food Recognition and Calorie Counter Application. 2017 IEEE 15th Student Conference on Research and Development (SCOReD), 445-450.

Olaoye, O. A., Onilude, A. A., \& Oladoye, C. O. (2007). Breadfruit Flour in Biscuit Making: Effects on Product Quality. African Journal of Food Science, 1(2), 21-23.

Tee, E. S., Ismail, M. N., Nasir, M. A., \& Khatijah, I. (1997). Nutrient Composition of Malaysian Foods: Malaysian Food Composition Database Programme. In Institute for Medical Research, Kuala Lumpur (p. 310).

Tee, W. (2020). Putu Piring. Myputupiring.Blogspot.My.

Yusnita, H., \& Wong, F. L. (2011). Physicochemical Properties and Acceptance of High Fibre Bread Incorporated with Corn Cob Flour. The 12th ASEAN Food Conference, 647-651. 